\section{Pathohistological aspects of pulmonary Langerhans cell histiocytosis}

Milana Panjkovic ${ }^{1,2}$, Mirjana Miladinovic ${ }^{3,4}$, Ljiljana Vučkovic ${ }^{3,4}$, Tanja Lakic ${ }^{1,2}$, Aleksandra Ilic ${ }^{1}$, Aleksandra Lovrenski ${ }^{2,5}$

${ }^{1}$ Clinical Center of Vojvodina, Novi Sad, Serbia;

${ }^{2}$ University of Novi Sad, Faculty of Medicine Serbia;

${ }^{3}$ Clinical Center of Montenegro, Podgorica, Montenegro;

${ }^{4}$ University of Montenegro, Faculty of Medicine Podgorica;

${ }^{5}$ Institute for Pulmonary Diseases of Vojvodina

\section{Abstract}

Pulmonary Langerhans cell histiocytosis (PLCH) is a rare disease of unknown etiology, which most commonly affects men, smokers, aged from 20 to 40. It is diagnosed by histological analysis of material obtained by lung biopsy, with immunohistochemical proving of Langerhans cells. The aim of this research is to determine pathohistological characteristics of PLCH and analyzing demographic, clinical and radiological parameters. Retrospective analysis of medical data for 13 patients, proven for PLCH at Institute for Pulmonary diseases of Vojvodina in period of fifteen years. PLCH was found at 9 $(69.3 \%)$ women and at $4(30.7 \%)$ men, average age 34.7 years. Main clinical symptoms were cough $(76.9 \%)$ and chest pain $(61.5 \%)$. Out of 13 patients, $11(84.6 \%)$ were smokers. In most cases PLCH histologically corresponded to the cellular phase of the disease $(46.1 \%)$, proliferative phase was present at $5(38.4 \%)$, and the fibrotic phase at $2(15.5 \%)$ patients. Immunohistochemically, Langerhans' cells were positive for presence of CD1a and S-100 antigens in all 13 of analyzed cases, while CD68 antigen was positive in 6 patients. In 6 patients $(46.2 \%)$ there was disease regression, and at 7 (53.8\%) patients the disease progressed despite the applied therapy. In our research, PHLC was more common in younger females, smokers with cough and chest pain. At most of the patients, histologically disease was in the cellular phase. Langerhans cells were positive to presence of CD1a and S100 antigens in all 13 patients. At more than half of the patients the disease progresses despite the applied therapy.

Ključne reči: Langerhans cells, histiocytes, pulmonary histiocytosis, immunohistochemical analysis.

\section{Patohistološki aspekti plućne histiocitoze Langerhansovih ćelija}

Milana Panjković1, ${ }^{1}$, Mirjana Miladinović3, ${ }^{3,}$, Ljiljana Vučković ${ }^{3,4}$, Tanja Lakić ${ }^{1,2}$, Aleksandra Ilić ${ }^{1}$, Aleksandra Lovrenski ${ }^{2,5}$

${ }^{1}$ Klinički centar Vojvodine, Novi Sad, Srbija

${ }^{2}$ Medicinski fakultet Univerziteta u Novom Sadu, Srbija

${ }^{3}$ Klinički centar Crne Gore, Podgorica, Crna Gora

${ }^{4}$ Medicinski fakultet Univerziteta u Crnoj Gori, Podgorica

${ }^{5}$ Institut za plućne bolesti Vojvodine, Novi Sad, Srbija

\section{Apstrakt}

Plućna histiocitoza Langerhansovih ćelija (PHLC) je retko oboljenje nepoznate etiologije od kojeg najčešće obolevaju muškarci, pušači, stari između 20 i 40 godina. Dijagnoza se postavlja pomoću histološke analize materijala dobijenog biopsijom pluća, uz imunohistohemijsko dokazivanje Langerhansovih ćelija. Cilj ovog istraživanja je utvrđivanje patohistoloških karakteristika PHLC i analiziranje demografskih, kliničkih i radioloških parametara. Retrospektivno je izvršena analiza medicinske dokumentacije 13 pacijenata kod kojih je na Institutu za plućne bolesti Vojvodine u petnaestogodišnjem periodu dokazana PHLC. PHLC nađena je kod 9 (69,3\%) žena i kod 4 (30,7\%) muškarca, prosečne starosti 34,7 godina. Glavni klinički simptomi bili su kašalj $(76,9 \%)$ i bol u grudima $(61,5 \%)$. Od 13 pacijenata $11(84,6 \%)$ bili su pušači. U većini slučajeva PHLC je histološki odgovarala celularnoj fazi bolesti $(46,1 \%)$, proliferativna faza bila je prisutna kod $5(38,4 \%)$, a fibrotična faza kod $2(15,5 \%)$ pacijenta. Imunohistohemijski, Langerhansove ćelije su u svih 13 analiziranih slučajeva bile pozitivne na prisustvo CD1a i S-100 antigena, dok je CD68 antigen bio pozitivan kod 6 pacijenata. Kod 6 pacijenata $(46,2 \%)$ došlo je do regresije bolesti, a kod $7(53,8 \%)$ pacijenata bolest je napredovala i pored primenjene terapije. $U$ našem istraživanju, PHLC je bila češća kod žena mlađe životne dobi, pušača sa kašljem i bolom u grudnom košu. Kod većine pacijenata bolest je histološki bila u celularnoj fazi. Langerhansove ćelije su kod svih 13 pacijenta bile pozitivne na prisustvo CD1a i S100 antigena. Kod više od polovine pacijenata bolest je progredirala i pored primenjene terapije.

Key words: Langerhansove ćelije, histiociti, plućna histiocitoza, imunohistohemijska analiza. 


\section{Introduction}

Pulmonary Langerhans cell histiocytosis - PLCH, is a disease of unknown etiology, with different clinical presentation and outcome. Most of the patients are active smokers, however, there is no correlation between intensity of smoking and disease severity ${ }^{1,2,3}$. Disease is 4 times more frequent in males than in females, and at $70 \%$ patients in II, III and IV decade of life ${ }^{1,4,5}$. The exact prevalence of disease is still unknown. It is certain that some cases are misdiagnosed as idiopathic pulmonary fibrosis and other diffuse interstitial lung diseases ${ }^{6,7}$.

Clinical signs and symptoms of disease are nonspecific, such as dyspnea and cough, which is often overlooked as a symptom because patients are most commonly smokers. Spontaneous pneumothorax with pleural pain and acute dyspnea, as first manifestation of this illness, appears in 10-20\% of the patients, and recurrent pneumothorax in $25 \%$ of the patients [8]. Hemoptysis is rare and more likely to refer to simultaneous presence of infection or a tumor. Around $25 \%$ of the patients do not display symptoms 9 .

Pulmonary histiocytosis is diagnosed based on anamnesis data, clinical examination of patient, pulmonary function tests, radiological, cytological and finally pathohistological findings.

Pulmonary function can be normal or there can be restrictive, obstructive or combined ventilation disorder ${ }^{10,11}$. The most common disorder is reduction of diffused capacity for carbon monoxide, that has been noticed in at least $70 \%$ of the patients $9,12,13$, which could be explained by affecting of vascular lung structures. Gas analyses of arterial blood at rest are commonly normal. Limitation of physical activity is at first caused by changes at blood vessels, and in the later phase by ventilation disorder as well ${ }^{14}$.

Radiological display of the disease is very characteristic with star shaped nodules, diameter from 2-10 $\mathrm{mm}$, reticule-nodular infiltrates, cysts in upper lobes and honeycomb shaped shadows, with sparing of the costophrenic angles ${ }^{11}$.

Computerized high resolution chest tomography (HRCT) can be diagnostic at (PLCH), especially when a combination of cysts and nodules in upper chest lobes is detected ${ }^{15}$. If this pattern is noted in patients with typical medical history, lung biopsy is not required for diagnosis. However, that kind of finding is rare ${ }^{12}$, most patients have either cysts or nodules, and then differential diagnosis is broader ${ }^{16}$.

Pleura thickening or pleural effusion are rare unless there is a data about previously treated pneumothorax. If the bones are affected as well, the lesions can be noted in ribs ${ }^{10,14}$.

Cytological bronchoalveolar lavage analysis (BAL) can be one of the diagnostic procedures, but it has a small diagnostic value. Langerhans cells in BAL can be identified by use of the monoclonal CD1a antibody. Nevertheless, this finding has small sensitivity and specificity because it is similar in smokers who do not suffer from this disease ${ }^{8,17}$.

The golden standard in diagnosing of pulmonary Langerhans cell histiocytosis is lung biopsy ${ }^{7,8,17}$. The aggravating factor for interpreting transbronchial lung biopsy findings is multifocal distribution of lesions. Open video assisted thoracoscopic lung biopsy is the most suitable diagnostic method because it bears the least operative risk. In patients with progressive disease and significant fibrosis, diagnosing is difficult because the number of Langerhans cells is decreasing in the tissue specimen and BAL. Therefore, the combination of transbronchial lung biopsy and BAL with identification of CD1a positive cells in the tissue and BAL liquid, is likely to lead to the correct diagnosis ${ }^{18}$.

Final diagnosis of PLCH is pathohistological with mandatory immunohistochemical analysis of the Langerhans cells phenotype. Langerhans cells show expression of CD1a antigen, S100, langerin, as well as poor positivity of CD68 antigen ${ }^{19}$.

Histologically, lesions in PLCH undergo through three phases: cellular, proliferative and fibrotic one. Early lesions are characterized by appearance of cellular interstitial infiltrates which consist of Langerhans cells, lymphocytes, macrophages, eosinophilic granulocytes, plasma cells and fibroblasts (cellular phase). These infiltrates form a histiocytic nodule which is normally localized around small airways ${ }^{20}$. In time, nodules cellularity is being lost, and the fibrous tissue multiplies (proliferative phase), so in the final phase there 
remains fibrotic star-shaped focus (fibrotic phase). In difficult cases there can be a lung fibrosis and creation of honeycomb lungs ${ }^{21}$. Evolution of pulmonary histiocytosis from cellular phase can go towards healing with minimal fibrosis, towards creation bronchiolitis obliterans or interstitial fibrosis and honeycomb lungs 2,16 .

The aim of our research was to determine epidemiological (occurrence of PLCH referred to sex and age of patients), clinical, radiological and pathohistological characteristics of pulmonary Langerhans cell histiocytosis.

\section{Material and methods}

Retrospective trial involved 16 patients proven for pulmonary Langerhans cell histiocytosis at Institute for Pulmonary Diseases of Vojvodina in Sremska Kamenica in period of fifteen years. Material for pathohistological analysis was processed in Center for Pathology. It was a retrospective research considering the fact that PLCH represents a rare pathological condition even in institutions specialized for respiratory system diseases.

Demographic and clinical-morphological data included in the research were: age, sex of the patients, smoking habits, disease symptoms, radiological characteristics of the changes in lung parenchyma and pathohistological and immunohistochemical characteristics of PLCH. All of the patients' data were obtained from their medical charts and pathohistological findings. The criteria for exclusion were a possible lack of information in medical data. Biopsy materials in patients with clinical and radiological changes were gained by open lung biopsy through video assisted thoracoscopy or thoracotomy. After the specimens were taken, they were sent to Center for Pathology where tissue specimens were processed by standard pathohistological analysis which includes: tissue fixation in $10 \%$ neutral formalin, molding tissue into paraffin blocks, cutting of preparation on microtome to 4 microns wide tissue cuts and dyeing of sample with haematoxilin-eosin (HE) method.

The specimens for immunohistochemical analyses were glued onto "Superfrost" (Men Glaser) positively electrified glass tiles, specially prepared for these analyses. After specimen deparafining, demasking of antigen determinants was performed by cooking of preparations in citrate puffer $(\mathrm{pH}=6)$ twice for ten minutes, and then cooling in distilled water during 20 minutes. After that, a 5 minute blocking of endogenous peroxides with $3 \%$ hydrogen $\left(\mathrm{H}_{2} \mathrm{O}_{2}\right)$ was performed.

These processed preparations were treated with primary antibodies for detection of Langerhans cell CD1a, S-100 and CD68. After that, the cuts were incubated for 30 minutes with biotinylated anti-mouse antibody, than incubated in another 30 minutes with streptavidin-peroxide complex system. DAB (diaminobenzidinetetrahidrochloride) was used as chrome substrate and contrasting with hematoxilin was performed.

Immunohistochemical specimens that were processed in that manner were then analyzed under light microscope and based on their positivity to certain antibody, a final diagnosis of PLCH was given.

The data obtained in the research were imported to specially created Microsoft Excel data base. The data were shown as distribution of frequencies and standard deviation was calculated. $\chi^{2}$ - test for determination of statistic significance was not calculated due to small case sample.

\section{Results}

The research included 16 patients with pathohistological diagnosis of pulmonary Langerhans cell histiocytosis. Three patients were excluded from the research due to the lack of information from medical charts. The youngest patient was 20 years old, the oldest was 64 years old. The average age of subjects was 34.7 years \pm SD 12 years. Out of 13 subjects, $9(69.3 \%)$ were females and $4(30.7 \%)$ were males.

The most common clinical manifestations in patients included in the research were cough, chest pain, dyspnea, pneumothorax, and hemoptysis. Most of the patients, 10 (76.9\%) of them, complained about cough, while chest pain appeared in $8(61.5 \%)$ patients. Dyspnea was present in $6(46.1)$ patients, while hemoptysis appeared in $2(15.3 \%)$ patients. In $5(38.46 \%)$ patients, spontaneous pneumothorax developed. 
Smoking is considered to be the most significant etiological factor for occurrence of pulmonary Langerhans cell histiocytosis. Out of all the subjects, $11(84.6 \%)$ were smokers, that have smoked in average 13.5 years and 20 cigarettes per day.

On chest radiogram in all patients, in both sides, a variety of pulmonary shadows were revealed, such as diffusely arranged cord-like and stain-like, tiny nodular shadows. In $8(61.6 \%)$ patients changes in lungs were localized in upper lobes, and in 5 (38.4\%) patients in middle and upper lung lobes. Lower lung parts and costophrenic sinuses were spared in all patients. HRCT was performed in all patients. In $6(46.2 \%)$ patients, disseminated nodular changes in lungs were present. In remaining 7 (53.8\%) patients, diffusely arranged cystic changes of unequal wall thickness were revealed. In $2(15.5 \%)$ patients lungs appeared as honeycombing.

In $6(46.1 \%)$ patients pulmonary Langerhans cell histiocytosis was in cellular phase, in $5(38.4 \%)$ patients in proliferative phase, and in remaining $2(15.5 \%)$ patients in fibrostic one.

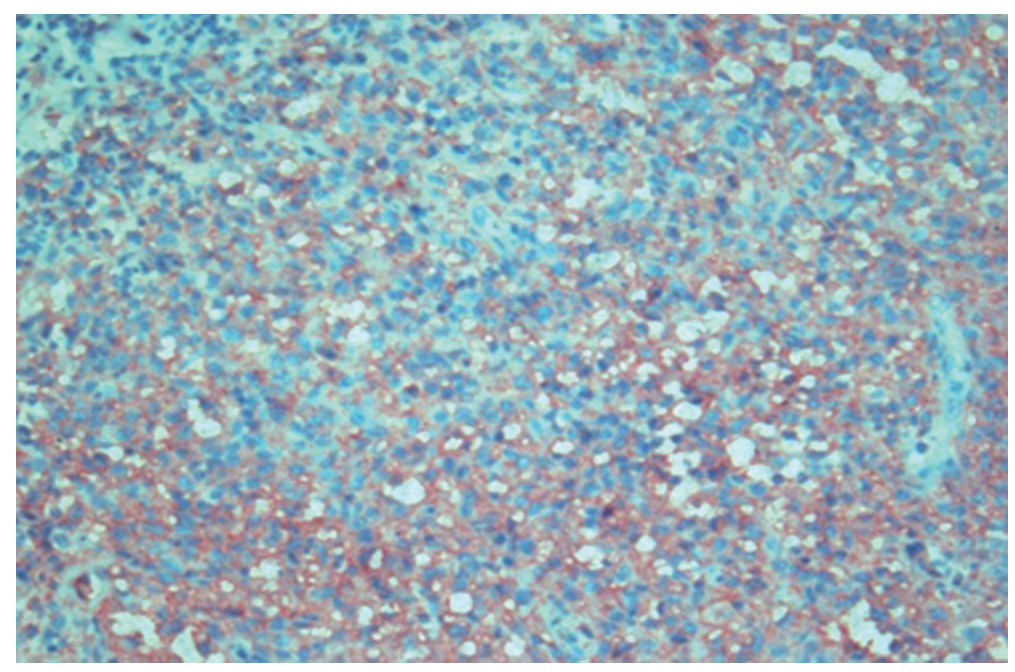

Figure 1. CD1a staining positive of Langerhans cell (400 x)

In all 13 patients, immunohistochemical analysis showed positivity of Langerhans cells to CD1a and S-100 (Figure 1. and 2.) and in 6 (46.1\%) patients CD68 positivity (Figure 3.)

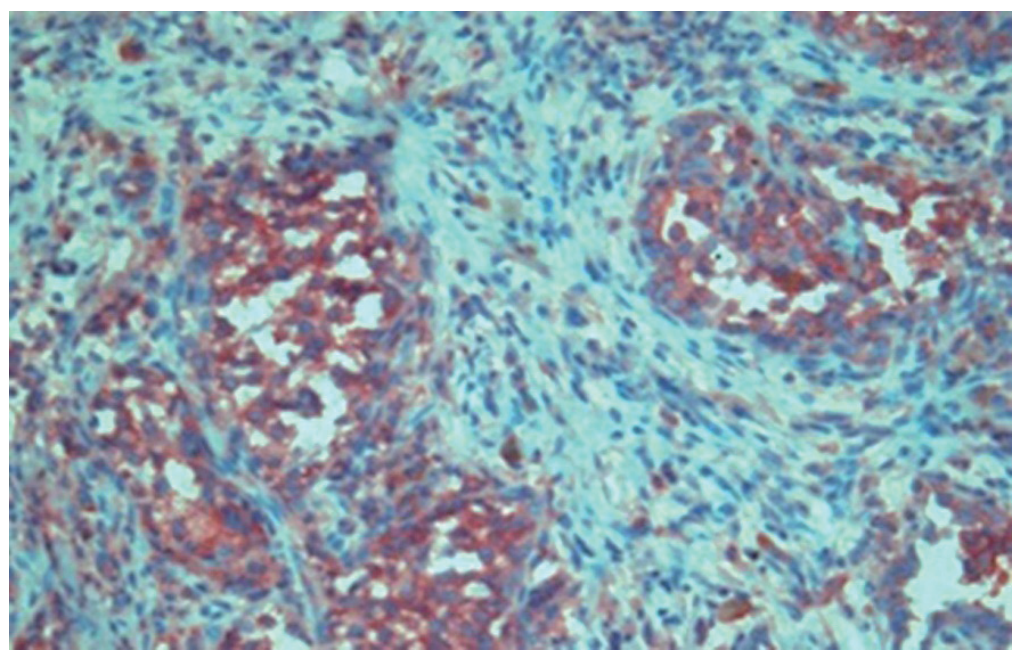

Figure 2. S-100 staining positive of Langerhans cell (400 x) 


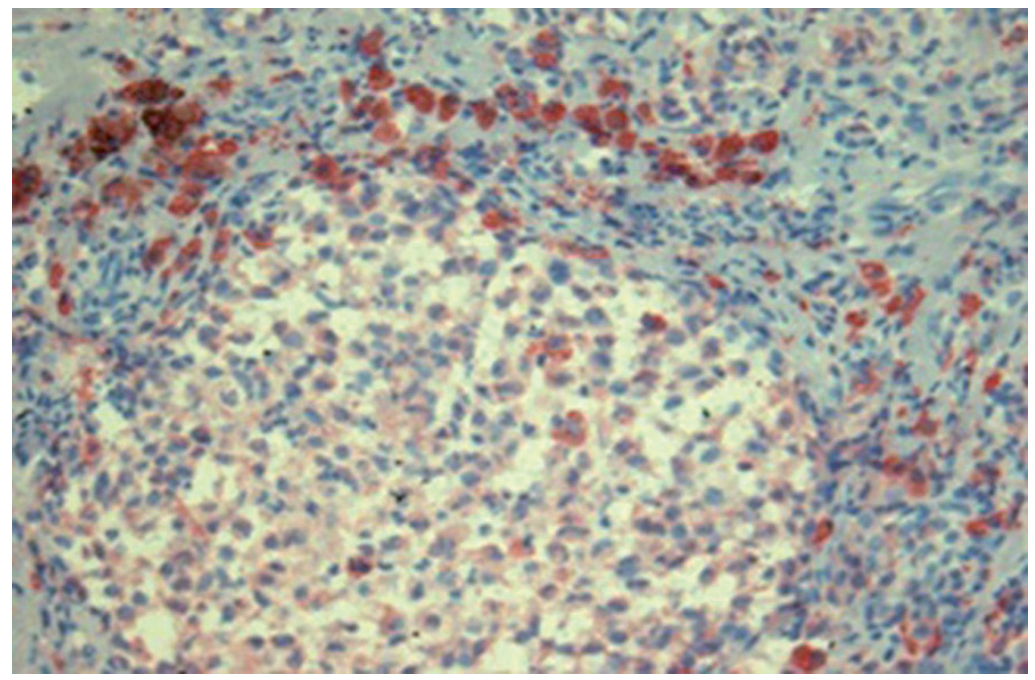

Figure 3. CD68 staining positive of Langerhans cell (400 x)

After PLCH was diagnosed, all of the patients received therapy. 12 patients (92.4\%) received corticosteroid therapy (Prednisone), while only one patient received cytostatic therapy (Vinblastin). Patients were monitored until the last regular follow up, with an average three years of monitoring period. During that time, in 6 (46.2\%) patients the clinical symptoms regressed after applied therapy. In 7 (55.8\%) patients the disease progressed despite therapy.

\section{Disscusion}

PLHC is a rare disease which could be discovered accidentally after occurrence of spontaneous pneumothorax or if symptoms such as nonproductive cough and dyspnea are present ${ }^{11}$. There are no clear epidemical data about incidence, but in great series of patients who had undergone open lung biopsy due to interstitial illness of unknown etiology, around 3.5\% Langerhans cell histiocytosis were registered ${ }^{1}$.

Mechanisms for PLCH are still wage. Correlation with smoking in 95\% people with diagnosed PLCH clearly indicates to the significant role of smoking in pathogenesis. There are several theories about how smoking cigarettes potentially facilitates formation of Langerhans cell nodules in lungs ${ }^{10,16}$. However, only a small percent of smokers develops PLCH, which imposes a need for further research of correlation between smoking and PLCH. Considering the close connection between PLCH and smoking, this disease is, together with RB-ILD (Respiratory Bronchiolitis-Interstitial Lung Disease) and DIP (Desquamative interstitial pneumonia), classified into so called SRILD (Smoking Related Interstitial Lung Disease).

In our study, most of patients were smokers, 11 out of $13(84.6 \%)$, who smoked averagely 13.5 years and 20 cigarettes per day. PLCH mainly affects younger, adult people, with the highest frequency between the ages twenty and forty ${ }^{6}$. The average age of our patients was 34.7 years and 11 of them was under 40, which corresponds to what literature states.

According to literature database, males are more commonly affected by the disease $e^{4,5,16}$. Nevertheless, in our patients, mainly females (69.3\%) were diagnosed with PLCH, rather than males $(30.7 \%)$.

Clinical manifestation of PLCH can be different ${ }^{3,20}$, despite diffusely affected lungs, symptoms such as cough and dyspnea are common and nonspecific in respiratory pathology, which aggravates PLCH diagnosing. Around $25 \%$ cases are manifested asymptomatically, while respiratory symptoms such as dry cough, chest pain and dyspnea occur in $2 / 3$ of cases. $60 \%$ of patients have at least one spontaneous pneumothorax episode ${ }^{14,22,23}$. By analyzing patients' medical charts, we have established that the most dominant clinical symptoms in our research were cough, which occurred in 10 of our patients $(76.9 \%)$, while chest pain was 
slightly rarer (61.5\%). Dyspnea was recorded in 6 patients $(46.1 \%)$, hemoptysis was present in 2 patients (15.5\%), while spontaneous pneumothorax was found in 5 patients $(38.4 \%)$.

Radiological manifestation of the disease is very characteristic with occurrence of both sided, diffusely arranged cord-like and stain-like, tiny nodular shadows. Typically, tiny nodular shadows occur in middle and upper parts, with sparing of the costophrenic angles ${ }^{11,24}$. High resolution chest tomography (HRCT) at the early phase of the disease most commonly displays characteristic disseminated nodular shadows. As the disease progresses, nodular shadows become cavitations, and in further development they can spontaneously disappear or become at first thick walls cysts, and then thin wall cysts. The cysts can enlarge and then become confluent, which could resemble emphysema ${ }^{18,25}$.

In our study, disseminated nodular shadows were noticed in $6(46.2 \%)$ patients. In remaining 7 (53.8\%) patients, diffusely arranged cystic changes of unequal wall thickness were present. In $2(15.5 \%)$ patients cystic changes progressed into bullous, and lungs appeared as honeycombing.

Final diagnosing of PLCH is achieved exclusively by pathohistological examination of bioptic material, but pathohistological analysis often needs complementation with use of immunohistochemistry. In our research, in 6 (46.1\%) patients PLCH was diagnosed in cellular phase, in 5 (38.4\%) in proliferative phase, and in $2(15.5 \%)$ patients in fibrotic one. The results obtained in our research do not differ significantly from other authors' data ${ }^{2}$. Pathohistological picture is characteristic, but in differential diagnosis, tumor-like Langerhans cell histiocytosis should be considered, which usually affects younger population, it is not related to smoking, and it is characterized with monoclonal Langerhans cells proliferation and affecting other organ systems (commonly skin and bones).

Langerhans cells display expression of antigens CD1a and S-100, and poor expression of CD68 antigen ${ }^{18,26}$. In our study, in all of the 13 patients, immunohistochemical analysis showed positivity of Langerhans cells to CD1a and S-100 antibody, while CD68 antibody has shown positivity in 6 cases.

For pulmonary histiocytosis treatment, different means are used, such as corticosteroids, monohemotherapy, surgical methods like sparing resections and purposeful radiotherapy ${ }^{27}$. It is mandatory to emphasize the necessity of smoking cessation, because with continuation of smoking, the disease gradually progresses, while smoking cessation leads to regression of changes in the lung. However, there have been reported cases of recidives and disease worsening despite smoking cessation ${ }^{28,29}$. Due to high rate of coherence between malignancy and PLCH, smoking cessation is the most important step in PLCH treatment ${ }^{16}$. Corticosteroid therapy is primarily used for symptomatic patients with dominant nodular lesions on HRCT, at the beginning with small doses of Prednisone, $0.5-1 \mathrm{mg} / \mathrm{kg}$, lasting from 6 to 12 months ${ }^{10,12}$. It remains unknown whether improvement is the result of the therapy itself or spontaneous recovery.

Cytotoxic therapy (especially Vinblastin), which was used occasionally, did not show final efficiency. Radiotherapy, singly or combined with other treatments, can achieve local control of unilocular or multilocular bone manifestations, but it is not useful in treatment of lung manifestations ${ }^{16}$. Pulmonary hypertension can be improved with therapy for pulmonary arterial hypertension. Pleurodesis can be required as optional therapy in patients with recurrent pneumothorax ${ }^{10,11}$. In our study, corticosteroid therapy (Prednisone) was applied in $12(92.4 \%)$ patients and only one (7.6\%) patient received cytostatic therapy (Vinblastin).

Lung transplantation is considered an optional method for patients in final phase of the disease, that suffer from pulmonary hypertension of medium to severe degree ${ }^{30}$, with ten-year survival rate over $50 \%$. Risk factors for disease occurrence in transplanted lungs are presence of extra lung lesions before the transplantation and smoking continuation after lung transplantation ${ }^{29,20}$. Therapies that might be useful in the future include gene therapy, monoclonal antibodies therapy and cytokines therapy ${ }^{7}$. Natural course of pulmonary histiocytosis is very divers. An unfavorable outcome is related with older age in the moment of confirmed diagnosis, severe obstruction of airways, diminished diffuse lung capacity, as well as the need for corticosteroids usage ${ }^{7}$.

About $50 \%$ of patients have favorable prognoses, while in $10-20 \%$ of patients fulminant course with mortal outcome occurs ${ }^{29}$. Our patients were regularly controlled until the last visit to the hospital in period from 1 to 6 years. In $7(53.8 \%)$ patients the disease progressed despite the applied therapy, while in $6(46.2 \%)$ patients 
the disease regressed gradually. Further research is needed in order to better understand pathophysiological mechanisms of this disease. The new researches are supposed to enable development and introduction of new treatment forms which will influence the disease course and outcome.

\section{Conclusion}

$\mathrm{PLCH}$ is a rare disease with nonspecific symptomatology which can easily be misdiagnosed as idiopathic lung fibrosis or other diffuse interstitial lung diseases and which is often related to higher risk for lung carcinoma occurrence and hematological malignancies with disease progression and high mortality rate. Precisely for these reasons, there is a need for interdisciplinary approach to this disease, in the sense of diagnostics as well as therapy. Although rare, this disease must be taken into consideration in differential diagnosis of pulmonary diseases, therefore the publication of results related to this entity is extremely important.

\section{References}

1. Harari S, Caminati A. Pulmonary Langerhans cell histiocytosis. In: Interstitial Lung Diseases: European Respiratory Monograph. 2009;155-75.

2. Lin MW, Chang YL, Lee YC, Cheng HL, Chen JS. Pulmonary Langerhans Cell Histiocytosis. Lung 2009;187(4):261-2.

3. Vassalo R, Ryu JH, Colby TV et al. Pulmonary Langerhans-cell histiocytosis. New Eng J Med 2000;342:1969-78.

4. Harpreet S, Eunhee Y, Gregorz N, Vassallo R. Pulmonary langerhans cell histiocytosis. Orphanet J Rare Dis. 2012;7:16.

5. Seely JM, Salahudeen S, Cadaval-Goncalves AT, Jamieson DH, Dennie CJ, Matzinger FR, Souza CA: Pulmonary Langerhans Cell Histiocytosis: A Comparative Study of Computed Tomography in Children and Adults. $J$ Thorac Imaging 2010.

6. King TE Jr. Pulmonary Langerhans'- cell histiocytosis. In: Fishman AP, Elias JA, Fishman JA, Grippi MA, Senior RM,Pack AI. eds. Fishman's pulmonary diseases and disorders. New York: McGraw-Hill; 2008:1245-54.

7. Lin M, Chang Y, Lee Y, Cheng H, Chen J, Hsu H. Pulmonary Langerhans Cell Histiocytosis. Lung. 2009;187(4):261-2.

8. Vermaelen K, Pauwels R: Pulmonary dendritic cells. Am J Respir Crit Care Med. 2005;172(5):530-51.

9. Tazi A. Adult pulmonary Langerhans' cell histiocytosis. Eur Respir J 2006; 27:1272-85.

10. Vassallo R, Ryu J, Schroeder DR, Decker PA, Limper AH. Clinical outcomes of pulmonary Langerhans'- cell histiocytosis in adults. N Engl J Med. 2002;346:484-90.

11. Watanabe R, Tatsumi K, Hashimoto S, Tamakoshi A, Kuriyama T; Respiratory Failure Research Group of Japan. Clinico-epidemiological features of pulmonary histiocytosis X. Intern Med. 2001;40:998-1003.

12. Bratke K, Klug M, Bier A, Julius P, Kuepper M, Virchow JC, Lommatzsch M: Function-associated surface molecules on airway dendritic cells in cigarette smokers. Am J Respir Cell Mol Biol. 2008;38(6):655-60.

13. Phillips M, Allen C, Gerson P, McClain K: Comparison of FDG-PET scans to conventional radiography and bone scans in management of Langerhans cell histiocytosis. Pediatric blood \& cancer. 2009;52(1):97-101.

14. Juvet SC, Hwang D, Downey GP. Rare lung diseases III: Pulmonary Langerhans' cell histiocytosis. Can Respir J. 2010;17(3):55-62.

15. Tazi A, Marc K, Dominique S, De Bazelaire C, Crestani B, Chinet T, Israel-Biet D, Cadranel J, Frija J, Bergeron A, et al: Evaluation Of The Course Of Adult Pulmonary Langerhans Cell Histiocytosis By Serial Lung Function Tests. Am J Respir Crit Care Med. 2011;183:A1620-10.

16. Cordier JF, Cottin V. Adult Langerhans' pulmonary cell histiocytosis. In: Palange P, Simonds A, eds. Respiratory medicine. Shefield: European Respiratory Society; 2010. p. 438-40.

17. Chang KL, Snyder DS. Langerhans cell histiocytosis. In: Ansell SM, ed. Rare hematological malignancies. New York: Springer;2008:383-96.

18. Sundar KM, Gosselin MV, Chung HL, Cahill BC. Pulmonary Langerhans cell histiocytosis: emerging concepts in pathobiology, radiology, and clinical evolution of disease. Chest. 2003;123:1673-83.

19. Kroening PR, Barnes TW, Pease L, Limper A, Kita H, Vassallo R: Cigarette smoke-induced oxidative stress suppresses generation of dendritic cell IL-12 and IL-23 through ERK-dependent pathways. J Immunol. 2008;181(2):1536-47.

20. Kaste SC, Rodriguez-Galindo C, McCarville ME, Shulkin BL: PET-CT in pediatric Langerhans cell histiocytosis. Pediatr Radiol. 2007;37(7):615-22.

21. Cerri S, Spagnolo P, Luppi F, Richeldi L. Smoking related interstitial lung disease. Eur Respir Mon. 2011;54:282-300.

22. Lin MW, Chang YL, Lee YC, et al. Pulmonary Langerhans cell histiocytosis. Lung. 2009;187:261-2. 
23. Abdellatif Tazi A, Marc K, Dominique S, de Bazelaire C, Crestani B, Chinet T, et al. Serial computed tomography and lung function testing in pulmonary Langerhans' cell histiocytosis. Eur Respir J. 2012;40:905-12.

24. Sholl LM, Hornick JL, Pinkus JL, Pinkus GS, Padera RF. Immunohistochemical analysis of langerin in langerhans cell histiocytosis and pulmonary inflammatory and infectious diseases. Am J Surg Pathol. 2007;31(6):947-52.

25. Lau SK, Chu PG, Weiss LM. Immunohistochemical expression of Langerin in Langerhans cell histiocytosis and nonLangerhans cell histiocytic disorders. Am J Surg Pathol. 2008;32(4):615-19.

26. Coury F, Annels N, Rivollier A, Olsson S, Santoro A, Speziani C, Azocar O, Flacher M, Djebali S, Tebib J, et al: Langerhans cell histiocytosis reveals a new IL-17 A-dependent pathway of dendritic cell fusion. Nat Med. 2008;14(1):81-7.

27. Konno S, Hizawa N, Betsuyaku T, et al. Adult Langerhans cell histiocytosis with independently relapsing lung and liver lesions that was successfully treated with etoposide. Intern Med. 2007;46:1231-5.

28. Yagci B, Varan A, Altinok G, Söylemezoglu F, Cila A, Büyükpamukçu M. Langerhans cell histiocytosis: Retrospective analysis of 217 cases in a single center. Pediatr Hematol Oncol. 2008;25:399-408.

29. Dauriat G, Mal H, Thabut G, et al. Lung transplantation for pulmonary langerhans' cell histiocytosis: A multicenter analysis. Transplantation. 2006;81:746-50.

30. Lazor R, Etienne-Mastroianni B, Khouatra C, Tazi A,Cottin V, Cordier JF. Progessive diffuse pulmonary Langerhanscell histiocytosis improved by cladribine.

Corresponding author:

Milana Panjković

21000 Novi Sad, Serbia

mob: +381638499908

e-mail: milana.panjkovic@mf.uns.ac.rs. 